\title{
Prevalence and factors associated with aflatoxin contamination of peanuts from Western Kenya
}

\author{
C.K. Mutegi ${ }^{\text {a,b,* }}$, H.K. Ngugi ${ }^{c}$, S.L. Hendriks ${ }^{\text {a }}$, R.B. Jones ${ }^{\text {d }}$ \\ a African Centre for Food Security, University of KwaZulu-Natal, Private Bag X01, Scottsville, 3209, South Africa \\ ${ }^{\mathrm{b}}$ Kenya Agricultural Research Institute, P.O Box 57811-00200, Nairobi, Kenya \\ c Department of Plant Pathology, Pennsylvania State University, 290 University Drive, Biglerville, PA 17307, USA \\ ${ }^{d}$ International Crops Research Institute for the Semi Arid Tropics (ICRISAT), P.O Box 39063-00623, Nairobi, Kenya
}

\section{A R T I C L E I N F O}

\section{Article history:}

Received 25 August 2008

Received in revised form 3 December 2008

Accepted 21 December 2008

\section{Keywords:}

Aflatoxin

Mycotoxins

Kenya

Groundnuts

\begin{abstract}
A B S T R A C T
Aflatoxin contamination of peanuts poses a risk to human health and has been identified as a major constraint to trade in eastern Africa. A survey was carried out to obtain baseline data on levels of aflatoxin in peanuts from major production regions in western Kenya. A total of 384 and 385 samples from Busia and Homabay districts, respectively, were obtained and analyzed for aflatoxin content with an indirect competitive ELISA protocol. Levels of aflatoxin ranged from 0 to 2688 and $7525 \mu \mathrm{g} / \mathrm{kg}$ in samples from Busia and Homa Bay, respectively. Of 769 samples, $87.01 \%$ contained $<4 \mu \mathrm{g} / \mathrm{kg}$ of aflatoxin, $5.45 \%$ were in the range $\geq 4$ and $20 \mu \mathrm{g} / \mathrm{kg}$, while $7.54 \%$ exceeded the Kenya's regulatory limit of $20 \mu \mathrm{g} / \mathrm{kg}$. There was a highly significant $\left(\chi^{2}=14.17 ; P<0.0002\right)$ association between district of origin and sample aflatoxin levels. This observation was supported by a significant $\left(\chi^{2}=11.98 ; P=0.0005\right)$ association between levels of aflatoxin and agro ecological zones. Only $3.26 \%$ of the samples from the dryer LM3 zone had $>20 \mu \mathrm{g} / \mathrm{kg}$ compared with $10.28 \%$ of the samples from the wetter and humid LM1 zone. There was also a highly significant $\left(\chi^{2}=9.73 ; P=0.0018\right)$ association between cultivar improvement status and aflatoxin levels. Logistic regression analysis revealed that the odds for peanuts from Busia being contaminated were 2.6 times greater than those for peanuts from Homabay. Planting improved cultivars would lower the odds of contamination to a half (odds ratio $=0.552$ ) those for local landraces. These results are discussed in relation to the risk of human exposure to aflatoxins and the need for proper sampling procedures for regulatory purposes.
\end{abstract}

(c) 2009 Elsevier B.V. All rights reserved.

\section{Introduction}

Peanut is an important crop in terms of nutrition and income in western Kenya. The nuts contain high levels of protein (Desai et al., 1999) and are relatively affordable compared to other sources of protein (Mayatepek et al., 1992). In western Kenya, peanut has the added appeal in that two crops can be harvested in a year. Western Kenya encompasses Nyanza and Western provinces, which are main peanut producing areas in the country according to the Crop Development Division Annual Report of 2004 (Anon, 2004). Nyanza province is the country's largest peanut producer with 14,723 ha under production while Western province with 2667 ha ranks third after Eastern province (Anon, 2004). Most of the produce is traded in local markets (Ogwang, 2006).

Aflatoxin contamination of peanuts poses a risk to human health and has been identified as a major constraint to trade in Africa (Lubulwa and Davis, 1994). Little is known about the prevalence or levels of aflatoxin in peanuts harvested in western Kenya. However,

\footnotetext{
* Corresponding author. Kenya Agricultural Research Institute, P.O Box 57811-00200, Nairobi, Kenya. Tel.: +254 $207224556 /+254734605268$

E-mail address: ckawirra@yahoo.com (C.K. Mutegi).
}

several indicators and anecdotal evidence suggest possible human exposure to aflatoxins. First, western Kenya has repeatedly recorded high levels of stunting in children (Central Bureau of Statistics, 2003), an aspect often positively correlated with long-term ingestion of sublethal doses of aflatoxin (Gong et al., 2002; Bhat and Vasanthi, 2003). Second, erratic rainfall, high temperatures and high humidity prevalent in the major production areas favour peanut contamination and development of aflatoxin. Wet and humid areas have been linked to higher levels of aflatoxin producing fungi in other parts of Eastern Africa (Udoh et al., 2000; Kaaya and Kyamuhangire, 2006) and Nigeria (Atehnkeng et al., 2008). Third, peanuts in Kenya are produced under small holder conditions, characterised by mechanical damage to pods, poor harvesting, drying and storage methods, linked to aflatoxin contamination of peanut elsewhere in sub-Saharan Africa (Jones and Duncan, 1981; Bilgrami and Choudhary, 1990; Waliyar et al., 2005a). Fourth, many farmers plant local varieties that are susceptible to disease such as rosette, mould and leaf spots (Ogwang, 2006). While disease and pests of peanut are common in western Kenya (Ngugi, H.K., personal communication), the small holder nature of peanut cultivation that uses minimal investment in inputs precludes the use of modern management tactics such as chemical pesticides; stress from disease and insect pests can predispose peanut plants to 


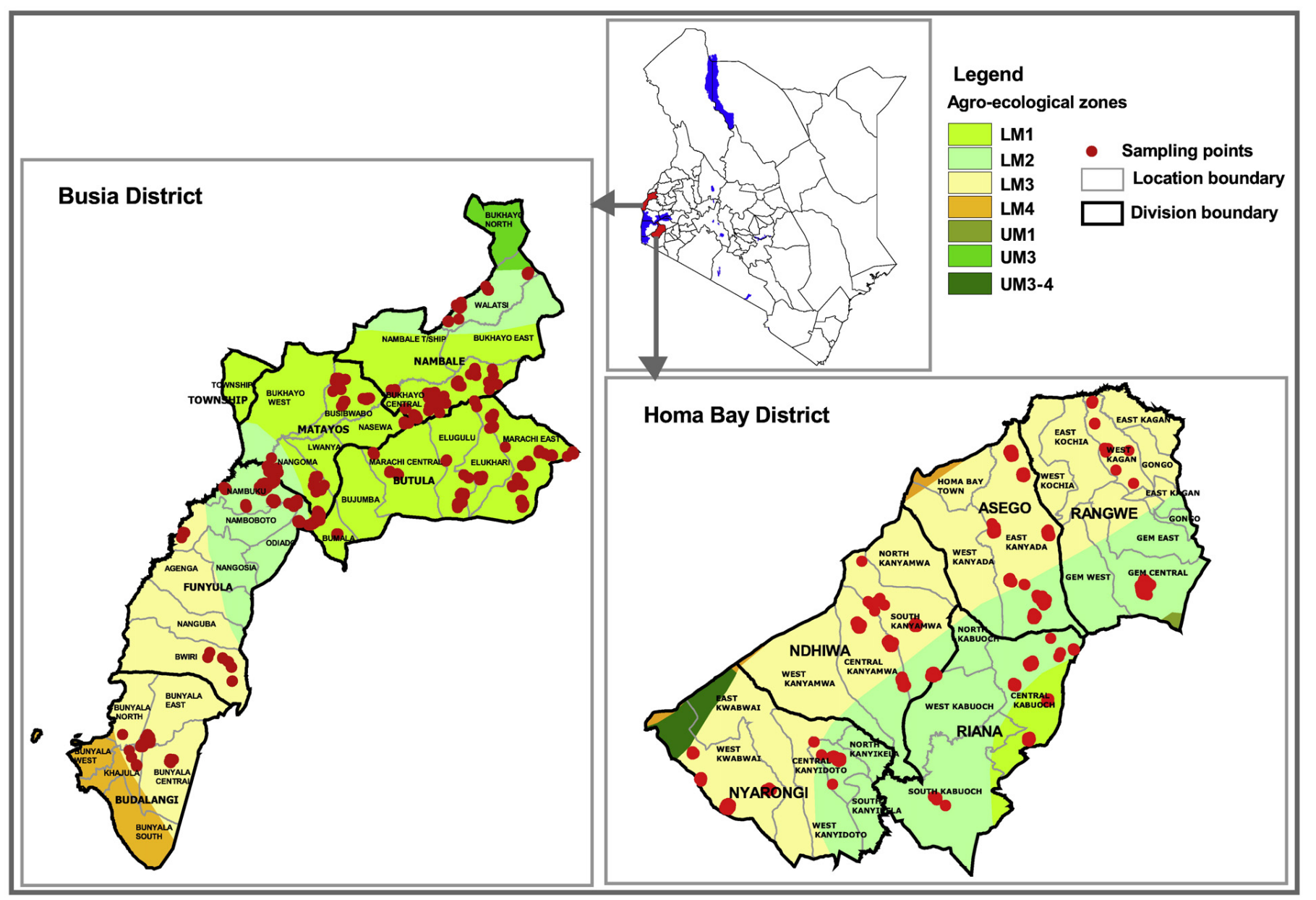


aflatoxin contamination (Hell et al., 2000; Chapin et al., 2004; Timper et al., 2004; Kaaya et al., 2005).

In spite of the paucity of data on aflatoxin, production of peanuts in western Kenya is on the increase due to recent initiatives. For example, the International Crops Research Institute for the Semi Arid Tropics (ICRISAT) has introduced improved varieties and seed bulking programs to meet increasing demand for high quality seed. Increased production will require peanut traders in the region to seek external markets that impose strict safety standards. These stringent measures are mainly driven by the health implications of aflatoxin, which is both carcinogenic and immunosuppressive (Fooladi and Farahnaky, 2003), and the toxin's common presence in peanut and maize commodities (Council for Agricultural Sciences and Technology, 1989). For example, the European Union (EU) market has a tolerance level of $2 \mu \mathrm{g} / \mathrm{kg}$ for aflatoxin B1 and $4 \mu \mathrm{g} / \mathrm{kg}$ for total aflatoxin for peanut kernels imported into the EU (Sobolev, 2007).

To ensure aflatoxin requirements for external markets are attained, there is a need to develop sampling procedures suited to local production systems and identify factors associated with high levels of aflatoxin contamination. Information on factors that influence the level of aflatoxin is critical to developing mitigating strategies appropriate for the region. This study was undertaken to: establish baseline levels of aflatoxin in peanuts harvested in western Kenya; identify factors associated with high levels of aflatoxin; and to model the relationship between these factors and the likelihood of a peanut sample from western Kenya exceeding the national aflatoxin regulatory threshold.

\section{Methods}

\subsection{Survey and peanut sample collection}

A household survey was carried out in Busia and Homabay districts in western Kenya (Fig. 1). These districts were chosen based on their significance in terms of peanut production, and because they offered a contrasting environment under which peanuts are cultivated. In Busia district, peanuts are mainly grown in the wetter and more humid Lower Midlands (LM) agro ecological zone (AEZ), otherwise referred to as LM1, in contrast with Homabay district where the crop is mainly produced in the drier LM3 zone.

The survey was based on a total of 769 peanut-growing households, with 384 and 385 respondents from Busia and Homabay districts, respectively. Information was collected through personal interviews using a pre-tested questionnaire, which was developed after conducting focus group discussions involving 40 and 44 participants from Busia and Homabay districts respectively. The participants were drawn from peanut farmers, village elders, community leaders and provincial administration staff. Thereafter a total of 40 randomly selected households were used to pre-test the developed questionnaire, 20 from Asego division of Homabay district and 20 from Butula division of Busia district. Each of the 40 households was selected by staggering every fourth household within the location administrative boundary, the starting point being the fourth household from the division's agricultural office from where activities for the day commenced.

For the purposes of sampling, the district was stratified into AgroEcological Zones (AEZs), namely LM1, LM2 and LM3, where peanut is commonly grown. The AEZs are determined based on altitude, mean annual rainfall, temperature, evapotranspiration and the probability of successfully growing the main crops of that zone (Jaetzold and Schmidt, 1982; Ngugi et al., 2002). The sample size for each AEZ was proportionate to acreage under peanut production (Table 1). Production statistics were obtained from the Ministry of Agriculture, while updated information on the AEZ mapping was acquired from the Geographic Information Systems Centre at the World Agro Forestry Centre, Nairobi, Kenya. Within the AEZs, farmers were randomly
Table 1

Number $^{\mathrm{a}}$ of peanut samples obtained from households in different agro ecological zones (AEZ) within each of the two districts surveyed in western Kenya, August 2006

\begin{tabular}{lccc}
\hline & District & \\
\cline { 2 - 3 } AEZ & Busia & Homabay & Total \\
\hline Lower Midland1 & $193(221)$ & $32(487)$ & 225 \\
Lower Midland 2 & $152(174)$ & $161(2455)$ & 313 \\
Lower Midland 3 & $39(45)$ & $192(2930)$ & 231 \\
Total $(n)$ & 384 & 385 & 769 \\
\hline
\end{tabular}

${ }^{\text {a }}$ Values in parenthesis represent peanut production in hectares.

selected at village level from a list compiled by the extension staff of the Kenya Ministry of Agriculture (MOA).

Data collected through the survey included farm size; whether or not respondents practiced crop rotation; number of times a crop was weeded per season; fertiliser use (whether commercial fertilisers, organic fertilisers or no fertiliser was used on the crop); pest and disease management practices (commercial pesticides, organic pesticides, cultural methods, and no control method at all); whether or not respondents perceived drought, erratic rainfall, damage by moles and/ or rats as production problems; type of cultivar(s) planted (whether improved or local landrace); aspects of peanut utilisation (e.g. methods of food preparation and whether crop was sold); and various aspects of awareness about aflatoxin. Farmers also were asked whether or not they belonged to a Producer Marketing Group (PMG); a PMG being a group of local peanut farmers brought together for the purposes of sourcing markets and to facilitate technology transfer (Mutegi et al., 2007). A $1 \mathrm{~kg}$ peanut sample was obtained from each interviewed household for aflatoxin testing. The sample was drawn from different parts of the farmer's storage container and thoroughly mixed. The samples were assayed for levels of aflatoxin as described below.

\subsection{Determination of levels of aflatoxin}

A $200 \mathrm{~g}$ sub-sample was drawn from each $1 \mathrm{~kg}$ sample and ground into a fine powder using a dry mill kitchen grinder (Kanchan Multipurpose Kitchen Machine, Kanchan International Limited, Mumbai, India). The ground sample was then sub-divided into two equal portions. The powder was triturated in $70 \%$ methanol (v/v $70 \mathrm{ml}$ absolute methanol in $30 \mathrm{ml}$ distilled water) containing $0.5 \% \mathrm{w} / \mathrm{v}$ potassium chloride in a blender, until thoroughly mixed. The extract was transferred to a conical flask and shaken for $30 \mathrm{~min}$ at $300 \mathrm{rpm}$. The extract was then filtered through Whatman No.41 filter paper and diluted 1:10 in phosphate buffered saline containing $500 \mu \mathrm{l} / 1$ Tween20 (PBS-Tween) and analyzed for aflatoxin with an indirect competitive ELISA (Waliyar et al., 2005b) by preparing an aflatoxinbovine serum albumin conjugate in carbonate coating buffer at $100 \mathrm{ng} / \mathrm{ml}$ concentration and dispensing $150 \mu \mathrm{l}$ in each well of the Nunc-Maxisorp® ELISA plates (Thermo Fisher Scientific Inc).

The plates were incubated at $37^{\circ} \mathrm{C}$ for $1 \mathrm{~h}$ before the toxin solution was collected and stored in a large glass bottle for disposal. The plates were washed in three changes of PBS-Tween, allowing a holding time of 3 min per wash. The plates were blocked with a $200 \mu \mathrm{l}$ per well solution of $0.2 \%$ bovine serum albumin (BSA) in PBS-Tween and incubated at $37{ }^{\circ} \mathrm{C}$ for $1 \mathrm{~h}$. The blocked plates were then washed in three changes of PBS-Tween allowing 3 min for each wash. To the washed plates, $100 \mu \mathrm{l}$ of peanut kernel extract was added followed by $50 \mu \mathrm{l}$ of antiserum. Instead of the peanut kernel extract, $100 \mu \mathrm{l}$ aliquots of different concentrations of AFB1 ( $25 \mathrm{ng}$ to $100 \mathrm{pg}$ ) were added into the first 20 wells (two rows of 10 wells each) to serve as a standard. The plates were then incubated for $1 \mathrm{~h}$ at $37{ }^{\circ} \mathrm{C}$ to facilitate reaction between the toxins and the antibody.

The plates were subsequently washed in three changes of PBSTween allowing $3 \mathrm{~min}$ for each wash. A dilution of 1:1000 goat antirabbit IgG labeled with alkaline phosphatase was prepared in PBSTween containing $0.2 \%$ BSA. A $150 \mu$ l aliquot was added to each well, 
Table 2

Amounts of aflatoxin with biological and/ or economic relevance used to establish frequency distributions of aflatoxin levels in Busia and Homabay districts

\begin{tabular}{|c|c|c|}
\hline $\begin{array}{l}\text { Category } \\
\text { mid-points } \\
\text { plotted }(\mu \mathrm{g} / \mathrm{kg})\end{array}$ & $\begin{array}{l}\text { Category based on } \\
\text { biological and/or } \\
\text { economic relevance } \\
(\mu \mathrm{g} / \mathrm{kg})\end{array}$ & Description of economic or biological relevance \\
\hline$\overline{0}$ & 0 & Undetectable levels \\
\hline 2 & $>0-\leq 4$ & $\begin{array}{l}\text { Permissible levels for total aflatoxins under } \\
\text { the EU regulations (Sobolev, 2007) }\end{array}$ \\
\hline 12 & $<20$ & $\begin{array}{l}\text { Permissible levels for total aflatoxins according } \\
\text { to KEBS (Mehan et al., 1991) }\end{array}$ \\
\hline 60 & $20-100$ & $\begin{array}{l}\text { Not safe for human consumption under } \\
\text { KEBS standards, but safe for animal feed } \\
\text { (Mehan et al., 1991) }\end{array}$ \\
\hline 550 & $100-1000$ & $\begin{array}{l}\text { Based on LD } 50 \text { of various animal species } \\
\text { (Mehan et al., 1991) }\end{array}$ \\
\hline 1500 & $1000-2000$ & $\begin{array}{l}\text { Based on LD } 50 \text { of various animal species } \\
\text { (Mehan et al., 1991) }\end{array}$ \\
\hline 4000 & $2000-6000$ & $\begin{array}{l}\text { Manifestation of sickness symptoms-nausea, } \\
\text { headaches, rush (http://ehs.ucdavis.edu/ucbso/ } \\
\text { FactSheet_Aflatoxin.html) }\end{array}$ \\
\hline
\end{tabular}

and incubated for $1 \mathrm{~h}$ at $37{ }^{\circ} \mathrm{C}$. The plates were washed in three changes of PBS-Tween, added a $150 \mu$ l per well of substrate solution (p-nitro phenyl phosphate prepared in 10\% diethanolamine buffer, $\mathrm{pH} 9.8$ ) and incubated for about $1 \mathrm{~h}$ at room temperature. Absorbance was measured at $405 \mathrm{~nm}$ in an ELISA plate reader (Multiskan Plus, Labsystems Company, Helsinki, Finland).

\subsection{Statistical analyses}

In order to characterise the distribution of aflatoxin levels, samples were grouped into categories with established economic (levels used to impose trade restrictions) or biological relevance (based on LD 50 of various animal species), based on their aflatoxin content (Table 2). For each district, the percentage of samples in each category was calculated and plotted against median values for the categories to obtain frequency distribution histograms. To test if the resulting frequency distributions were similar for the two districts, the data were subjected to Kolmogorov-Smirnoff and the Mann-Whitney $U$ two samples tests (Sprent and Smeeton, 2001). Several probability distribution models (negative binomial, gamma and lognormal distributions) were also evaluated for their ability to describe the frequency distributions. Goodness of fit for the probability distribution models was assessed by analysis of deviance using GenStat Ver 9.1 (Lawes Agricultural Trust, Rothamsted Experimental Station).

To identify factors associated with different levels of aflatoxin, the samples were grouped into three categories based on their aflatoxin

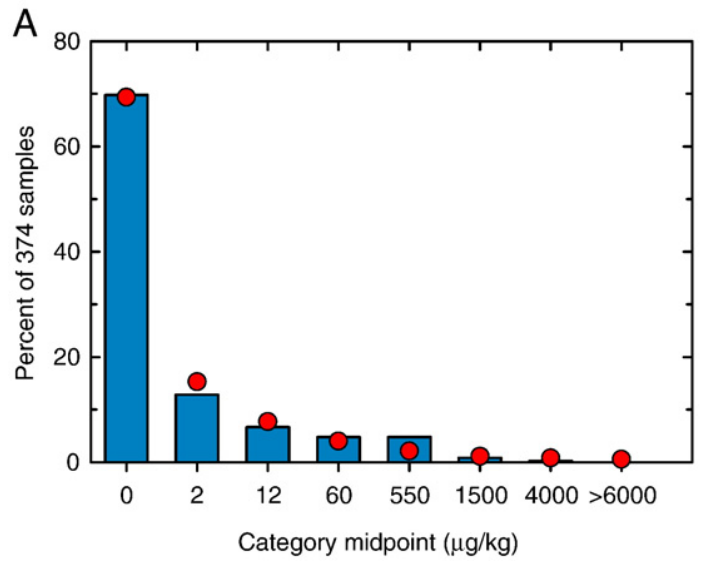

content: samples with $<4 \mu \mathrm{g} / \mathrm{kg} ; \geq 4 \mu \mathrm{g} / \mathrm{kg}$ to $\leq 20 \mu \mathrm{g} / \mathrm{kg}$, and $>20 \mu \mathrm{g} /$ $\mathrm{kg}$. The $<4 \mu \mathrm{g} / \mathrm{kg}$ category represents the EU regulatory limit for total aflatoxins (Felicia, 2004); peanuts in the second group would be rejected in the EU but accepted under the Kenya Bureau of Standards (KEBS) limits (Felicia, 2004), while nuts in the third category would be rejected under the KEBS and EU standards. Categorical data analysis by means of contingency tables was used to assess for association between these aflatoxin categories and descriptive variables.

The relationship between factors identified as significantly associated with levels of aflatoxin and the likelihood of a sample exceeding Kenya's regulatory limit of $20 \mu \mathrm{g} / \mathrm{kg}$ (here-after considered contaminated) was modelled using a logistic regression approach. The binary response variable was the sample level of aflatoxin (AL) whereby $1 \geq 20 \mu \mathrm{g} / \mathrm{kg}$ and $0=<20 \mu \mathrm{g} / \mathrm{kg}$. All variables with a significant association $(P<0.05)$ were tested as explanatory variables and those found to be insignificant were dropped to obtain the most parsimonious model. Categorical data analyses (Stokes et al., 2000) were carried out using SAS Ver. 9.1 (SAS Institute, Carry, NC).

\section{Results}

\subsection{Levels of aflatoxin in peanut samples from Busia and Homabay districts}

The levels of aflatoxin ranged from 0 to $2687.6 \mu \mathrm{g} / \mathrm{kg}$ and from 0 to $7525.0 \mu \mathrm{g} / \mathrm{kg}$ in samples from Busia and Homabay districts, respectively. Overall, $63.7 \%$ of all samples had undetectable levels of aflatoxin while $7.54 \%$ were contaminated based on KEBS standards; $2.1 \%$ of the samples were unsuitable even for animal feed (i.e. exceeded $100 \mu \mathrm{g} / \mathrm{kg}$ ) based on FDA action levels. Kolmogorov-Smirnoff (K-S) and the Mann-Whitney $U$ two samples tests (Sprent and Smeeton, 2001) showed that the frequency distributions of aflatoxin levels in samples from the two districts were significantly different (K-S $P=0.325$; Mann-Whitney $U$-test: $P=0.798$ for equal distribution). For both districts, however, the resulting distributions were highly skewed to the left indicating that most of the samples were safe based on the KEBS and EU regulatory limits (Fig. 2). The distributions were generally well fitted by gamma, negative binomial and lognormal distributions with the gamma distribution providing the best fit for samples from the two districts (e.g. deviance values for the three models were $=17.94,22.72$ and 36.13 , respectively, for samples from Busia district).

\subsection{Factors associated with levels of aflatoxin}

Fig. 3A shows percentage of samples in each of the three categories of aflatoxin levels plotted against the district of origin, i.e. Busia or

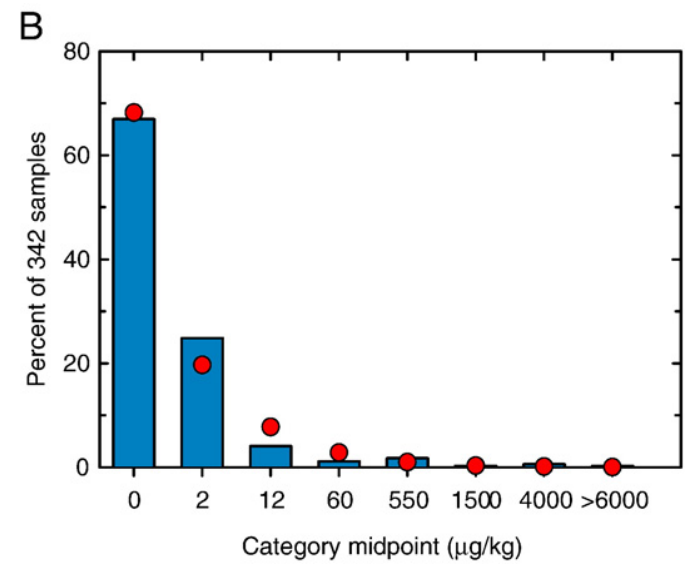

Fig. 2. Frequency distribution of levels of aflatoxin in peanuts from Busia (A) and Homabay (B) based on mid-points of aflatoxin categories with biological and/or economic importance. Fitted values are frequencies obtained from fitting the gamma probability distribution function to the observed values. 
A
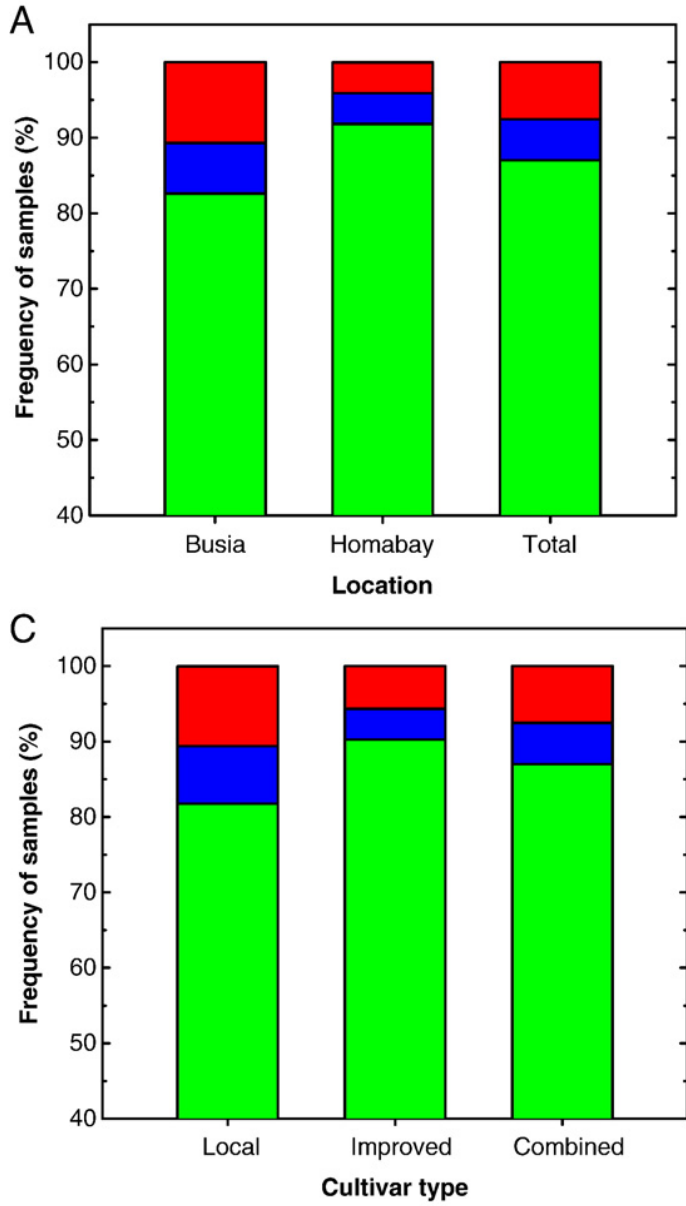

B

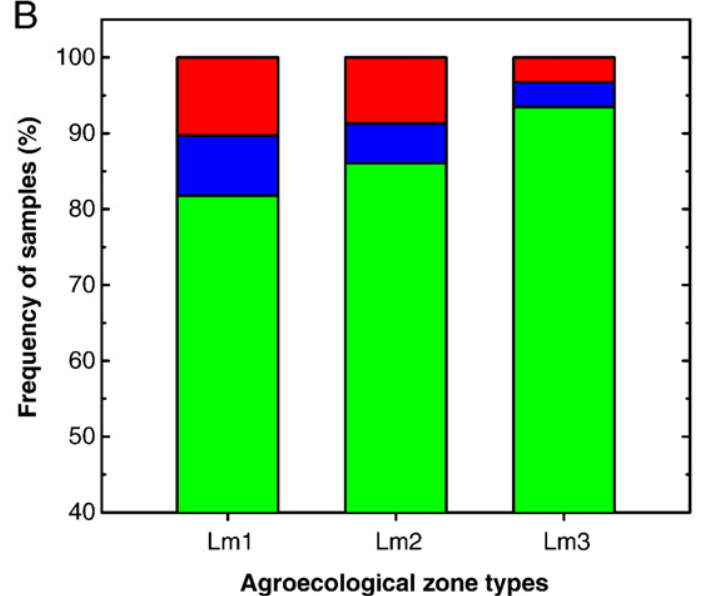

D

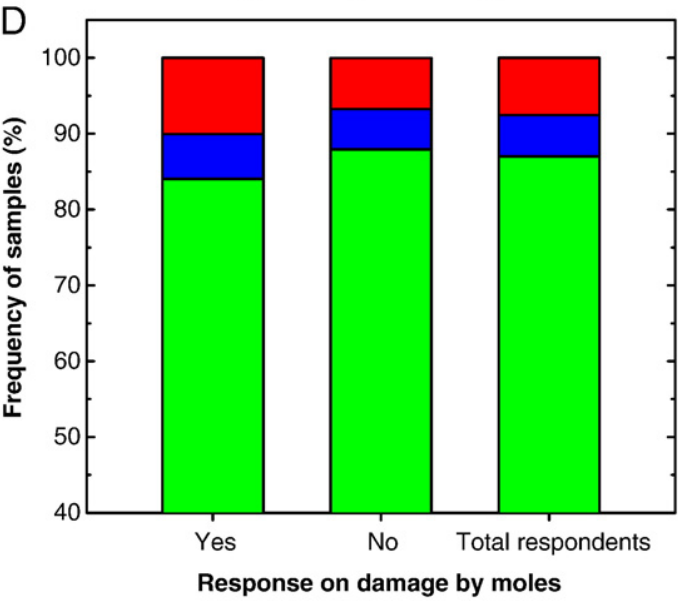

Fig. 3. Percentage of samples in the three categories of levels of a
response to whether or not the crop was damaged by moles (D).

Homabay. A highly significant association $\left(\chi^{2}=14.172 ; P=0.0002\right)$ was found between district of sample origin and aflatoxin levels. The percentage of safe samples according to KEBS standards was lower in Busia district (82.62\%) compared to Homabay district (91.81\%). While $10.70 \%$ of samples from Busia district had aflatoxin levels $>20 \mu \mathrm{g} / \mathrm{kg}$, only $4.09 \%$ of samples from Homabay were in this category.

There was a highly significant $\left(\chi^{2}=11.983 ; P=0.0005\right)$ association between AEZ and aflatoxin levels. A pattern was also noted whereby, the percentage of contaminated samples declined with decreasing precipitation across the region (i.e. from the wet LM1 AEZ to the drier LM3 AEZ; Fig. 3B). The frequency of samples containing $<4 \mu \mathrm{g} / \mathrm{kg}$ of aflatoxin was $81.78 \%$ in LM1, 86.06\% in LM2 and $93.49 \%$ in LM3. Conversely, samples with aflatoxin levels of $\geq 20 \mu \mathrm{g} / \mathrm{kg}$ were $10.28 \%$ in LM1, 8.71\% in LM2 and 3.26\% in LM3. Samples that would have otherwise been accepted under the KEBS regulations but rejected under the EU regulations were 7.94\%, 5.23\% and 3.26\% for LM1, LM2 and LM3, respectively.

A strong association was noted between levels of aflatoxin and cultivar improvement status (improved versus local landrace) whereby improved cultivars had significantly lower percentages of contaminated samples ( $\chi^{2}=9.748 ; P=0.0018$ as shown in Fig. 3C). Indeed, for cultivars with a sufficient sample size $(n>45)$ a significant association $\left(\chi^{2}=4.27 ; P=0.0388\right)$ between individual cultivars and levels of aflatoxin was also noted, with more samples from the im- proved cultivars having lower levels of aflatoxin compared to the local cultivars (Table 3). For example, while improved cultivars ICGV 12988 and ICGV 12991 had $92.75 \%$ and $95.56 \%$ of their samples respectively below $4 \mu \mathrm{g} / \mathrm{kg}$, Homabay Local and Local Red had 87.16 and $77.78 \%$ in the same category. On the other hand, ICGV 12988 and ICGV 12991 had $5.80 \%$ and $4.44 \%$ of the respective samples with aflatoxin levels $\geq 20 \mu \mathrm{g} / \mathrm{kg}$, while Homabay Local and Local Red had $4.59 \%$ and $15.97 \%$ of the samples in this category.

Table 3

Association between levels of aflatoxin and cultivars commonly grown in Busia and Homabay districts of western Kenya, August 2006

\begin{tabular}{llrllc}
\hline Cultivar & $\begin{array}{l}\text { Status of } \\
\text { cultivar }^{\mathrm{a}}\end{array}$ & $n$ & \multicolumn{3}{l}{$\begin{array}{l}\text { Percent of samples with different levels } \\
\text { of aflatoxin }\end{array}$} \\
\cline { 3 - 6 } & & & $<4 \mu \mathrm{g} / \mathrm{kg}$ & $\leq 4-<20 \mu \mathrm{g} / \mathrm{kg}$ & $\geq 20 \mu \mathrm{g} / \mathrm{kg}$ \\
\hline CG7 & $\mathrm{I}$ & 74 & 89.19 & 8.11 & 2.70 \\
Homabay local & $\mathrm{L}$ & 109 & 87.16 & 8.26 & 4.59 \\
ICGV88 & $\mathrm{I}$ & 69 & 92.75 & 1.45 & 5.80 \\
ICGV 12991 & $\mathrm{I}$ & 135 & 95.56 & 0.00 & 4.44 \\
Local red & $\mathrm{L}$ & 144 & 77.78 & 6.25 & 15.97 \\
Uganda red & $\mathrm{I}$ & 100 & 81 & 9.00 & 10.00 \\
Valencia red & $\mathrm{I}$ & 47 & 91.49 & 2.13 & 6.38 \\
\hline
\end{tabular}

$\chi^{2}=4.27 ; P=0.0388$.

a Local landrace $=\mathrm{L}$; improved variety $=\mathrm{I}$. 
Table 4

Parameter estimates from a logistic regression relating levels of aflatoxin with district of sample origin and cultivar improvement status

\begin{tabular}{llllcr}
\hline Parameter & DF & Estimate & SE & Wald $\chi^{2}$ & $P>\chi^{2}$ \\
\hline Intercept & 1 & -2.306 & 0.215 & 115.11 & $<0.0001$ \\
District & 1 & 0.488 & 0.161 & 9.18 & $<0.0024$ \\
Cultivar improvement & 1 & -0.594 & 0.288 & 4.27 & 0.0387 \\
\hline
\end{tabular}

A significantly higher proportion of samples obtained from farmers who reported damage from moles as a problem had higher levels of aflatoxin compared with those from farmers who had not experienced rodent damage. While $83 \%$ of peanut samples from farmers reporting moles as a problem had less that $4 \mu \mathrm{g} / \mathrm{kg}$ per sample, over $88 \%$ of the samples from farmers who had no problem with this pest were in this category of less than $4 \mu \mathrm{g} / \mathrm{kg}\left(\chi^{2}=4.449 ; P=0.0349\right.$; Fig. 3D).

Although the proportion of samples with $<20 \mu \mathrm{g} / \mathrm{kg}$ of aflatoxin was numerically higher for farmers belonging to PMGs (which, among other activities train farmers on methods to mitigate aflatoxin contamination) than non PMG members, the association was not statistically significant $\left(\chi^{2}=3.61 ; P=0.0573\right)$. No significant association was detected between levels of aflatoxin and use of fertilisers; number of times the crop was weeded; application of crop rotation; disease and pest control or drought during the cropping season.

\subsection{Relationship between factors associated with high levels of aflatoxin and the likelihood of finding a contaminated sample}

Logistic regression analysis indicated that aflatoxin level (AL) was only significantly affected by district of sample origin (DT), and cultivar improvement status (CIP). There was no significant interaction between district of sample origin and cultivar improvement status (Table 4). The negative value of the estimate CIP indicates that samples obtained from improved cultivars were less likely to exceed the regulatory limit. The fitted model describing this relationship was: logit $(A L)=-2.306+0.051$ DT -0.594 CIP. The test for goodness-of-fit $(D=0.968 ; P=0.325)$ indicated that the model fitted the data well. Including AEZ as an explanatory variable did not significantly improve the fit of the model. Based on this model, the odds of a sample from Busia exceeding Kenya's regulatory limit $(20 \mu \mathrm{g} / \mathrm{kg})$ were 2.65 times higher (Wald $\chi^{2}=9.183 ; P=0.0024$ ) those for a sample from Homabay district. The odds for a sample from an improved cultivar exceeding this threshold were a half (odds ratio $=0.552$ ) of those for a sample obtained from a local landrace.

\section{Discussion}

In this study, the prevalence and levels of aflatoxin in peanuts from western Kenya were investigated. The factors associated with high levels of aflatoxin were identified, and the risk of a peanut sample from the region exceeding the national regulatory threshold of $20 \mu \mathrm{g}$ / $\mathrm{kg}$ was determined. The results indicate that the levels of aflatoxin ranged from 0 to $>7525 \mu \mathrm{g} / \mathrm{kg}$ and were highly variable; that most peanuts from western Kenya are generally safe for human consumption but a small proportion of the samples contained very high levels of aflatoxin. The data also show that peanuts from local landraces and those harvested in the more humid agro-ecological zones within the region were more likely to be contaminated with aflatoxin than those from improved cultivars and/or from less humid agro-ecological zones.

The data for describing the incidence of aflatoxin levels were well fitted by gamma, negative binomial and lognormal probability distributions. This observation has two key implications. First, in comparing levels of aflatoxin for any grouping variable (e.g. AEZs, cultivars, agronomic practices, etc.), the median will be a more appropriate statistic than the arithmetic mean, because of the highly skewed distribution of the levels as shown by frequency plots. The second implication is that in designing sampling protocols for regulatory purposes, the skewed nature of the distributions in incidence of aflatoxin levels will need to be taken into account. By identifying the gamma distribution as the most suitable function for analyzing data on the incidence of aflatoxin, the results also accord well with those of Berry and Day (1973) who recommended the gamma distribution for modelling levels of aflatoxin when most samples contain undetectable levels. This was based on their study with data on dietary aflatoxin samples from Murang'a district in central Kenya.

Over $92 \%$ of the samples were within Kenya's regulatory limit (20 $\mu \mathrm{g} / \mathrm{kg}$ ), while over $87 \%$ of the samples were also within the more strict EU regulatory limit of $4 \mu \mathrm{g} / \mathrm{kg}$ indicating that at household level, most peanuts have acceptable levels of aflatoxin. These results are consistent with studies conducted elsewhere in Africa. For example, a survey carried out in Egypt reported low levels of aflatoxin in unshelled and shelled raw peanuts (El-Khadem, 1990) while in postharvest surveys on rain fed and irrigated peanuts in Sudan, none of the samples obtained from the households visited contained aflatoxin levels of more than $15 \mu \mathrm{g} / \mathrm{kg}$ (Singh et al., 1989).

This study also showed lower levels of aflatoxin contamination of peanuts at household level compared to maize as has been reported in the survey of 350 maize products conducted in Kenya including in the Busia district in 2004, whereby $>55 \%$ of the samples exceeded the $20 \mu \mathrm{g} / \mathrm{kg}$ limit while $35 \%$ had aflatoxin levels $>100 \mu \mathrm{g} / \mathrm{kg}$ (Lewis et al., 2005). This observation implies that the risk of human exposure to aflatoxin from consumption of peanuts is much lower than that associated with contaminated maize. The significance of this observation is clearer when one considers that in Kenya peanut is eaten as a side dish, sauce or snack and consumed in relatively small amounts compared to maize, which is consumed in larger amounts of $0.4 \mathrm{~kg} /$ person/day (Shepherd, 2003).

Nevertheless, a market survey of peanut aflatoxin contamination would be insightful in understanding the contribution of market outlets to the risk of aflatoxin exposure since additional contamination and aflatoxin accumulation can occur at various stages in the informal peanut marketing cycle. The likelihood of higher contamination in market outlets increases when one looks at previous studies, that have documented high fungal and aflatoxin prevalence and incidence in marketed peanut kernels and their by products (Verma and Agarwal, 2000; Ila et al., 2001; Le Anh, 2002). This infers that greater contamination than present at harvest may occur during the peanut marketing chain.

Of all the factors studied, only the source of sample origin (district or agro ecological zone), damage by moles, cultivar improvement status and cultivar type were significantly associated with the levels of aflatoxin in peanut samples. Previously, it was documented that significant correlations between AEZ and aflatoxin levels existed, whereby a wet and humid climate tends to aggravate aflatoxin levels. In neighboring Uganda for example, aflatoxin levels in maize samples were higher in more humid areas compared to the drier areas (Kaaya et al., 2006) and similar results were obtained in a recent survey of maize samples from Nigeria (Atehnkeng et al., 2008). The significantly higher odds of peanuts from the Busia district being contaminated compared with those from the Homabay district could be partly attributed to the distribution of AEZ within the districts; the wetter and humid LM1 is mainly found in Busia district while the drier LM3 is mainly found in Homabay district. It is difficult to pinpoint the specific causes of higher levels of aflatoxin in the wet humid zone, but it is probable that high moisture does not allow for sufficient drying of nuts, that are in most cases dried on bare ground or polythene mats in homesteads or in fewer instances dried in the field, in the study regions. This is feasible due to frequent rainfall during the peanut harvesting months of July and December. However, it is not possible to conclusively resolve the issue in the present study because the peanut samples analyzed were taken from on-farm storages, probably well 
after aflatoxin production had occurred. Regardless of the actual causes, strategies aimed at mitigating the aflatoxin contamination and human exposure will likely be more effective if they are targeted to the more wet and humid areas of the Busia district.

Unimproved local varieties were associated with higher levels of aflatoxin compared to improved cultivars. These results concur with the work of Hell et al. (2003) who documented a positive correlation between local varieties and increased aflatoxin levels of maize in Benin. The resistance status of the cultivars assessed in this study to colonization by aflatoxin-producing Aspergillus species is not known. However, improved varieties generally tend to be selected for increased yield and resistance to diseases that may reduce their susceptibility to infection by Aspergillus sp. Moreover, local landraces such as Homabay Red, Uganda Red and Red Valencia, have been reported to be susceptible to rosette, stem rot and mold (Ogwang, 2006), and positive correlations between disease and aflatoxin contamination of peanuts have been documented by many researchers (Lynch and Wilson, 1991; Udoh et al., 2000; Kasno, 2004; RobertsonHoyt et al., 2007).

Attack by moles also was found to be significantly associated with aflatoxin levels. Damage by moles predisposes pods to colonization by aflatoxin producing fungi, and similar damage by terrestrial arthropods has been reported (Dicko et al., 1999). At the same time the damage increases moisture levels of pods and grains, as documented by Hell et al. (2000). Pod damage also exposes the kernels to colonization by aflatoxin-producing and other saprophytic fungi (Chapin et al., 2004).

The observation that membership in a PMG was not significantly associated with levels of aflatoxin was surprising because PMG members are trained on pre- and post-harvest peanut handling practices that should result in a reduction in the level of contamination (Mutegi et al., 2007). The reasons for this observation were not investigated but it is possible that the awareness-raising program has not been undertaken long enough to have had an impact. The specific message being delivered through the PMGs may also need to be reviewed to ensure more aspects about aflatoxin, especially practices that reduce the level of peanut contamination are covered. Identifying the reasons why PMGs were apparently not effective at reducing the aflatoxin contamination is essential since long-term strategies for aflatoxin control will depend on the use of such groups as avenues for disseminating the appropriate control strategies. In the short term, the risk of aflatoxin exposure in western Kenya can be minimized by directing control strategies on the more humid agro ecological zones such as LM1, emphasizing planting of improved cultivars and protecting the crop from damage by rodents.

\section{Acknowledgements}

The authors thank the Catholic Relief Services (CRS) and Kenya Ministry of Agriculture-Extension Services for their support in data collection, the International Crops Research Institute for the Semi Arid Tropics (ICRISAT) and KARI for funding and logistical support, and Veera Reddy (ICRISAT) for technical assistance.

\section{References}

Anonymous, 2004. Crop Development Division Annual Report. Ministry of Agriculture, Nairobi.

Atehnkeng, J., Ojiambo, P.S., Donner, M., Ikotun, T., Sikori, R.A., Cotty, P.J., Bandyopadhyay, R., 2008. Distribution and toxigenicity of Aspergillus species isolated from maize kernels from three agro-ecological zones in Nigeria. International Journal of Food Microbiology 122, 74-84.

Berry, G., Day, N.E., 1973. The statistical analysis of the results of sampling an environment for a contaminant when most samples contain an undetectable level. American Journal of Epidemiology 97, 160-166.

Bhat, R.V., Vasanthi, S., 2003. Mycotoxin food safety risk in developing countries. International Food Policy Research Institute. Focus 10, Brief 3 of 17.

Bilgrami, K.S., Choudhary, A.K., 1990. Incidence of Aspergillus flavus in the aerosphere of maize fields at Bhagalpur. Indian Phytopathology 43, 38.
Central Bureau of Statistics, 2003. Multiple Indicator Cluster Survey (MICS) Report Ministry of Planning and National Development, Nairobi, pp. 31-32.

Chapin, J.W., Dorner, J.W., Thomas, J.S., 2004. Association of a burrower bug (Heteroptera cydnidae) with aflatoxin contamination of peanut kernels. Journal of Entomological Science 39, 71-83.

Council for Agricultural Science and Technology, 1989. In: Nisi, K.A. (Ed.), Mycotoxins: Economical and Health Risks. Council for Agricultural Science and Technology, Ames, lowa, pp. 1-91.

Desai, B.B., Kotecha, P.M., Salunkhe, D.K., 1999. Science and Technology of Groundnut: Biology, Production, Processing and Utilization. First edition. Naya Prokash, Bidhan Sarani, Calcutta, p. 196.

Dicko, I.O., Traore, S., Traore, D., Dao, B., 1999. Distribution of damage by terrestrial arthropods on groundnuts (Arachis hypogaea L.) in Burkina Faso. Tropicultua 16/17, 43-46.

El-Khadem, M., 1990. Aflatoxins in Egyptian peanut: an overview. Zeitschrift für Pflanzenkrankheiten und Pflanzenschutz 97, 233-236.

Felicia, W.U., 2004. Mycotoxin risk assessment for the purpose of setting international regulatory standards. Environmental Science and Technology 38, 4049-4055.

Fooladi, M.H., Farahnaky, A., 2003. Aflatoxin removal from Pistachio nuts by natural natrolite. Journal of Food Science 68, 1225-1228.

Gong, Y.Y., Cardwell, K., Hounsa, A., Egal, S., Turner, P.C., Hall, A.J., Wild, C.P., 2002 Dietary aflatoxin exposure and impaired growth in young children from Benin and Togo: a cross sectional study. British Medical Journal 325, 20-21.

Hell, K., Cardwell, K.F., Poehling, H.M., 2003. Relationship between management practices, fungal infection and aflatoxin for stored maize in Benin. Journal of Phytopathology 151, 690-698.

Hell, K., Cardwell, K.F., Setamou, M., Poehling, H.M., 2000. The influence of storage practices on aflatoxin contamination in maize in four agro-ecological zones of Benin, West Africa. Journal of Stored Products Research 36, 365-382.

http://ehs.ucdavis.edu/ucbso/FactSheet_Aflatoxin.html. Biological Safety Working Group Fact Sheet, Office of Environment, Safety and Health, University of California. Accessed on 2/2/2008.

Ila, P., Chauhan, S.S., Singh, K.S., 2001. Studies on the infestation of aflatoxin B1 in poultry feeds in the Tarai region of Uttar Pradesh. Indian Journal of Poultry Science 36, 221-223.

Jaetzold, R., Schmidt, H., 1982. Farm Management Handbook of Kenya, Vol.11, West Kenya (Nyanza and Western provinces). Ministry of Agriculture, Kenya and German Agricultural Team (GAT) of the German Technical Cooperation (GTZ), Rossdolf, pp. 397

Jones, R.K., Duncan, H.E., 1981. Effect of nitrogen fertilizer, planting date and harvest date on aflatoxin production in corn inoculated with Aspergillus flavus. Plant Disease 65, $741-744$.

Kaaya, A.N., Kyamuhangire, W., 2006. The effect of storage time and agro ecological zone on mould incidence and aflatoxin contamination of maize from traders in Uganda. International Journal of Food Microbiology 110, 217-223.

Kaaya, A.N., Kyamuhangire, W., Kyamanywa, S., 2006. Factors affecting aflatoxin contamination of harvested maize in the three agro-ecological zones of Uganda. Journal of Applied Sciences 6, 2401-2407.

Kaaya, A.N., Warren, H.L., Kyamanywa, S., Kyamuhangire, W., 2005. The effect of delayed harvest on moisture content, insect damage, moulds and aflatoxin contamination of maize in Mayuge district of Uganda. Journal of the Science of Food and Agriculture $85,2595-2599$

Kasno, A., 2004. Prevention of Aspergillus flavus infection and aflatoxin contamination in groundnut. Jurnal Penelitian dan Pengembangan Pertanian 23, 75-81.

Le Anh, P., 2002. Aspergillus flavus contamination of maize and groundnut oil cake and applied rapid test for the detection of aflatoxigenic strains. Khoa Hoc Ky Thuat Thu Y (Veterinary Sciences and Techniques) 9, 54-59.

Lewis, L., Onsongo, M., Njapau, H., Schurz-Rogers, H., Luber, G., Kieszak, S., Nyamongo, J., Backer, L., Dahiye, A.M., Misore, A., DeCock, K., Rubin, C., 2005. Aflatoxin contamination of commercial maize products during an outbreak of acute aflatoxicosis in Eastern and Central Kenya. Environmental Health Perspectives 113, 1763-1767.

Lubulwa, A.S.G., Davis, J.S., 1994. Estimating the social costs of the impacts of fungi and aflatoxins in maize and peanuts. In: Highley, E., Wright, E.J., Banks, H.J., Champ, B.R (Eds.), Stored Product Protection, Proceedings of the 6th International Working Conference on Stored-product Protection, 17-23 April 1994, Canberra, Australia vol. 1, pp. 1017-1042.

Lynch, R.E., Wilson, D.M., 1991. Enhanced infection of peanut, Arachis hypogaea L., seeds with Aspergillus flavus group fungi due to external scarification of peanut pods by the lesser cornstalk borer, Elasmopalpus lignosellus (zeller). Peanut Science 18 110-116.

Mayatepek, E., Atinga, P.E.W., Mrotzek, M., Bremer, H.J., 1992. Food survey and chemica composition of food and ready-to-eat meals in the Luo area of south western Kenya. Ecology of Food and Nutrition 26, 259-269.

Mehan, V.K., McDonald, D., Haravu, L.J., Jayanthi, S., 1991. Limits and regulations. The Groundnut Aflatoxin Problem: Review and Literature Database. Patancheru, A.P.502 324, India, pp. 185-193.

Mutegi, C.K., Hendriks, S.L., Jones, R.B., Okello, J.J., Ngugi, H.K., 2007. Role of collective action and handling practices on aflatoxin contamination of groundnuts: evidence from Kenya. Proceedings of the African Crop Science Conference, 27-31 October 2007, El-Minia, Egypt, vol. 8, pp. 1779-1782.

Ngugi, H.K., King, S.B., Abayo, G.O., Reddy, Y.V.R., 2002. Prevalence, incidence, and severity of sorghum diseases in western Kenya. Plant Disease 86, 65-70.

Ogwang, T., 2006. Status of Groundnut Production in Busia District: Lucrative Legume Project. Stakeholders Meeting, Milimani Resort, Kisumu. Friday, February 10th 2006

Robertson-Hoyt, L.A., Payne, G.A., Isakeit, T., Maragos, C.M., Molnar, T.L., Holland, J.B. 2007. Relationships among resistances to Fusarium and Aspergillus ear rots and contamination by fumonisin and aflatoxin in maize. Phytopathology 99, 311-317. 
Shepherd, G.S., 2003. Aflatoxin and food safety: recent African perspectives. Journal of Toxicology 22, 267-286.

Singh, B., Khalid, A.S., Magboul, B., Okezie, B.O., Anderson, J.C., Wheelock, G.C., Jones, H., Caples, V., 1989. Aflatoxin contamination of groundnuts with special reference to Sudan and some Caribbean countries. Aflatoxin Contamination of Groundnut: Proceedings of the International Workshop, 6-9 October, 1987, ICRISAT, India, vol. 14, pp. 245-253.

Sobolev, V.S., 2007. Simple, rapid and inexpensive cleanup method for quantitation of aflatoxins in important agricultural products by HPLC. Journal of Agricultural and Food Chemistry 55, 2136-2141.

Sprent, P., Smeeton, N.C., 2001. Applied Nonparametric Statistical Methods, 3rd Edition. Chapman \& Hall/CRC Texts in statistical sciences, Boca Raton, FL

Stokes, M.E., Davis, C.S., Koch, G.G., 2000. Categorical Data Analysis Using the SAS System, Second edition. SAS Institute, Cary, NC, p. 626.

Timper, P., Wilson, D.M., Holbrook, C.C., Maw, B.W., 2004. Relationship between Melodogyne arenaria and aflatoxin contamination in peanut. Journal of Nematology $36,167-170$.
Udoh, J.M., Cardwell, K.F., Ikotun, T., 2000. Storage structures and aflatoxin content of maize in five agro ecological zones of Nigeria. Journal of Stored Products Research 36, 187-201.

Verma, R.K., Agarwal, R.K., 2000. Occurrence of aflatoxin in groundnut and groundnut cake available at distributors and retailers of Uttar Pradesh. Indian Journal of Animal Nutrition 17, 156-159.

Waliyar, F., Natre, B.R., Traore, A., Diarra, B., Kodio, O., Kumar, P.L., 2005a. Pre and post harvest management of aflatoxin contamination in groundnut. International Crops Research Institute for the Semi Arid Tropics: Institut d'Economie Rurale (IER), Mali. www.aflatoxin.info. Accessed on 1/12/2005.

Waliyar, F., Reddy, S.V., Kumar, P.L., 2005b. Estimation of Aspergillus flavus infection and aflatoxin contamination in Seeds: Laboratory Manual. International Crops Research Institute for the Semi-Arid Tropics, Patancheru 502 324, India, p. 26. 